the national effort, it was decided to maintain the provision for the current year at the same level as that of 1939 , namely, $£ 2,149,000$. These considerations, he said, have lost none of their force, and despite the increasing strain on the national finances the Government, after considering a report from the University Grants Committee, have reached the conclusion that if the universities are to continue their present contribution to the national effort the provision for 1941 must be maintained at the existing level. He expressed the hope that local authorities will take similar action.

\section{Precautions against Blister Gas Attacks}

As a precautionary measure, which is being taken to cope with the possible use of blister gas by the enemy in aerial attacks on Great Britain, pharmacists are to be asked to provide supplies to the public of 'bleach cream'. The Ministry of Home Security, which has been in collaboration with the Pharmaceutical Society, is responsible for the scheme. Briefly, the Ministry has invited all proprietors of pharmacies, by a letter addressed to each one of them, to make 'bleach cream' available for members of the public in the event of blister gas being dropped in the vicinity of their pharmacies. The plan is quite simple; it is that the proprietor of each pharmacy, having been provided by the local authority with two enamel pails and a supply of 'tropical bleach' for the preparation of bleach cream, should, when and if gas is first used, place the pails furnished with cream on the pavement outside his shop with a poster instructing the public how to apply it. No charge would be made to the public, and it has been agreed with the Pharmaceutical Society that pharmacists should be asked to perform this service without payment as part of their contribution to the national effort.

\section{An Ichthyosaurian Fossil}

According to a report published by the daily Press, a nearly complete skeleton of an Ichthyosaurian, or fish-shaped fossil reptile, has been found in the shaft of the Hermann Göring Mine in the northern Harz Mountains. It is to be studied by Prof. J. Weigelt, of Halle, who estimates its length as $5 \cdot 10$ metres, or nearly 17 feet. Such well-preserved large skeletons are very rare and difficult to extract from the rock in a perfect state. The largest Ichthyosaurian skeleton in the British Museum, which was obtained from the Lower Lias of Lyme Regis, Dorset, would measure about 24 feet in length when it was complete. Several known Ichthyosaurian skulls from the Lias belong to individuals which must have been at least 30-40 feet long. One of the finest of these large skulls, from Lyme Regis, is exhibited in the rooms of the Geological Society of London at Burlington House.

\section{Classification of Ships and Machinery}

The Thomas Lowe Gray Lecture to the Institution of Mechanical Engineers on January 24 by Dr. S. F. Dorey was on the "Progress in Marine Engineering as Influenced by the Classification of Ships". The classification of ships sprang out of the ancient practice of marine insurance, and has been in vogue for nearly two centuries. There are many classifica. tion societies ; but the best known is Lloyd's Register of Shipping of which Dr. Dorey is the chief engineer surveyor. These classification societies serve the interests of shipowners, shipbuilders, engineers, underwriters and others, and each of them has rules relating to the construction and maintenance of ships and their machinery. Giving a sketch of the development of marine machinery since the earliest steamboats, Dr. Dorey traced the rules by which Lloyd's Register has influenced progress. From the first specification for machinery, right through the period of its construction and at regular periods during its life, Lloyd's surveyors have duties to perform, and the whole shipping industry owes much to the impartial and exceptional way those duties are performed. From its very constitution a classification society is strictly impartial; it is a form of voluntary control of an industry by the industry for the general well-being.

\section{Factory Canteens}

The Factory (Canteens) Order of the Minister of Labour, whereby all factories doing Government contract work and employing 250 persons are required to provide canteen facilities either in or near the workshops, has opened up new problems to the management of factories (Electrician, Jan. 17). In the first place, factory meals will, of necessity, be inexpensive, and of the various cooking processes involved, boiling and steaming will be in preponderance for such items of diet as stews, steamed puddings, rice and vegetables of various kinds. Ample steaming oven accommodation must therefore be made for the large quantities of steamed food, and steam boiling pans for greens, stews, etc. Electric cooking has the advantage that the air is not vitiated by the products of combustion, and ventilation problems are, therefore, usually less acute. The usual number of air changes per hour normally allowed for a kitchen is of the order of 20-60; this could be modified, depending on the provision for natural ventilation. In using electricity for thermostaically controlled instantaneous boilers to deliver water near boiling point, it is best to arrange that the demand occurs during the peak period of the load on the public power station.

\section{Molybdenum and Tungsten in the Caucasus}

IT is announced by "Russia Today" Press Service that large molybdenum and tungsten works have been opened recently in Kabardino-Balkaria, in the Caucasian mountains. The plant is situated at the foot of Mount Tyrny-Auz. Soviet geologists began to prospect for ores on this mountain in 1934. At an altitude of $9,850 \mathrm{ft}$. they discovered large deposits of rich molybdenum and tungsten ores. Owing to the situation of the Tyrny-Auz deposits, however, the extraction of the ores has presented a difficult problem, and local weather is severe. Everything about the workings is mechanized. The ore, which is extracted by means of electric drills, is brought away 